GRASAS Y ACEITES 68 (4)

October-December 2017, e226

ISSN-L: 0017-3495

doi: http://dx.doi.org/10.3989/gya.0667171

\title{
Characterization of pecan nut expeller cake and effect of storage on its microbiological and oxidative quality
}

\author{
L. Marchetti ${ }^{\mathrm{a}, \bigotimes}$, L. Romero ${ }^{\mathrm{b}}$, S.C. Andrés ${ }^{\mathrm{a}}$ and A.N. Califano ${ }^{\mathrm{a}}$ \\ ${ }^{a}$ Centro de Investigación y Desarrollo en Criotecnología de Alimentos (CIDCA), CONICET, CICPBA, Facultad de Ciencias \\ Exactas, UNLP. 47 y 116, La Plata (1900), Argentina. \\ ${ }^{\mathrm{b}}$ Laboratorio de Investigación y Desarrollo de Métodos Analíticos (LIDMA), CONICET, Facultad de Ciencias Exactas, UNLP, 47 y \\ 116, La Plata (1900), Argentina. \\ ${ }^{\otimes}$ Corresponding author: marchetti.lucas@gmail.com
}

Submitted: 19 June 2017; Accepted: 28 September 2017

\begin{abstract}
SUMMARY: Pecan nut expeller cake (PNEC), a by-product of pecan oil extraction, was characterized and the effect of packaging and storage conditions was investigated. Samples were packaged under vacuum or in normal atmosphere and stored $\left(10\right.$ or $\left.20^{\circ} \mathrm{C}\right)$ for 12 months. Its composition, water and oil absorption, fatty acids profile, lipid oxidation (thiobarbituric acid reactive substances, TBARS), antioxidant activity [Diphenyl-1-(2,4,6trinitrophenyl)hydrazyl] radical, $\mathrm{DPPH}^{\bullet}$ and [(2,2'-azinobis-(3-ethylbenzothiazoline-6-sulfonic acid)] radical cation, $\left.\mathrm{ABTS}^{\bullet+}\right)$, and microbiological quality were analyzed. PNEC showed high lipid and fiber contents (51.4 and $21.6 \mathrm{~g} / 100 \mathrm{~g}$, respectively) with good water and oil absorption capacity. Vacuum storage at $10{ }^{\circ} \mathrm{C}$ preserved antioxidant capacity (TBARS: malondialdehyde $=0.23 \mathrm{mg} / \mathrm{kg}, \mathrm{IC}_{50} \mathrm{DPPH}=9.0 \mathrm{mg} / \mathrm{mL}$, and $\mathrm{IC}_{50} \mathrm{ABTS}=$ $21 \mathrm{mg} / \mathrm{mL}$ after one year storage). Extremely low mold and yeast levels were found in PNEC in low permeability vacuum packages, regardless of the storage temperature. Thus, PNEC could retain suitable quality attributes for up to 12 months using the right combination of packaging and temperature.
\end{abstract}

KEYWORDS: Antioxidant capacity; Fatty acid profile; Pecan nut expeller cake; Storage; TBARS

RESUMEN: Caracterización de la torta prensada de nuez de pecan y efecto del almacenamiento sobre su calidad microbiológica y oxidativa. La torta de prensada de nuez de pecan (PNEC), un sub-producto dela extracción de aceite de pecan, fue caracterizado y se investigó el efecto del embalaje y condiciones de almacenamiento. Las muestras fueron envasadas con y sin vacío y almacenadas $\left(10\right.$ o $\left.20^{\circ} \mathrm{C}\right)$ durante 12 meses. Se analizó la composición, absorción de agua y aceite, perfiles de ácidos grasos, oxidación lipídica (sustancias reactivas al ácido tiobarbitúrico, TBARS), actividad antioxidante [radical (difenil-1-(2,4,6-trinitrofenil) hidracilo] DPPH ${ }^{\bullet}$ y catión radical [ácido (2,2'-azinobis-(3-etilbenzotiazolin-6-sulfónico)], ABTS ${ }^{\bullet+}$ ) y calidad microbiológica. El PNEC mostró altos contenidos de lípidos y fibra (51.4 y $21.6 \mathrm{~g} / 100 \mathrm{~g}$, respectivamente) con buenas capacidades de absorción de agua y aceite. El almacenamiento bajo vacío a $10^{\circ} \mathrm{C}$ preservó la capacidad antioxidante (TBARS: malondialdehído, $\mathrm{MDA}=0.23 \mathrm{mg} / \mathrm{kg}, \mathrm{IC}_{50} \mathrm{DPPH}=9.0 \mathrm{mg} / \mathrm{mL}$, y IC $\mathrm{IC}_{50} \mathrm{ABTS}=21 \mathrm{mg} / \mathrm{mL}$ luego de un año de almacenamiento). Los recuentos de hongos y levaduras fueron extremadamente bajos en los tratamientos con vacío y envases de baja permeabilidad, para ambas temperaturas. Por lo tanto, el PNE pudo retener adecuados atributos de calidad hasta 12 meses empleando la adecuada combinación de envase y temperatura.

PALABRAS CLAVE: Almacenamiento; Antioxidante; Perfil de ácidos grasos; TBARS; Torta de prensada de nuez pecan

ORCID ID: Marchetti L http://orcid.org/0000-0002-0451-2826, Romero L http://orcid.org/0000-0003-3020-1746, Andrés SC http://orcid.org/0000-0002-4032-9607, Califano AN http://orcid.org/0000-0002-3872-4130

Citation/Cómo citar este artículo: Marchetti L, Romero L, Andrés SC, Califano AN. 2107. Characterization of pecan nut expeller cake and effect of storage on its microbiological and oxidative quality. Grasas Aceites $\mathbf{6 8}$ (4), e226. http:// dx.doi.org/10.3989/gya.0667171

Copyright: (C2017 CSIC. This is an open-access article distributed under the terms of the Creative Commons Attribution (CC-by) Spain 3.0 License. 


\section{INTRODUCTION}

Pecan nuts(Caryaillinoinensis), native to the U.S. and north of Mexico, belong to the Juglandaceae family which also includes walnuts (Juglans sp.) (Hal, 2000). Mainly produced in the U.S., production is gradually increasing in Argentina. Pecan nut seeds are a rich source of lipids, mainly composed of mono- and polyunsaturated fatty acids (> 70\% of total lipids; Fernandes et al., 2017) Pecans are in the top 15 foods known for their antioxidant activity according to the USDA (Haytowitz et al., 2006). They contain many phyto-chemical substances that may contribute to their overall antioxidant activity (E vitamin, $\beta$-carotene, lutein, zea-xanthin) (Pinheiro do Prado et al., 2009) and several important B-complex vitamins (riboflavin, niacin, thiamin, pantothenic acid, vitamin B-6, folates), minerals (manganese, potassium, calcium, iron, magnesium, zinc, selenium), and phytosterols (b-sitosterol, stigmasterol, campesterol) (USDA, 2016; Fernandes et al., 2017).

Pecan oil is an edible pressed oil extracted from the nut; it is neutral in flavor, rich in unsaturated fatty acids, mainly oleic and linoleic acids (67.55 and $20.67 \%$, respectively, Fernándes et al., 2017), and considered a healthy specialty gourmet product (Cockerham et al., 2012). However, the industrialization of pecan nuts to produce oil has a substantial amount of by-products. This relative simple process employs a mechanical extrusion to obtain oil by pressing nuts with a screw press, which then requires filtering (Walsh, 2016). The by-product is a highly-unsaturated lipid pecan meal (pecan nut expeller cake, PNEC) that tends to rapidly oxidize and loose quality during storage (Cockerham et al., 2012) due to its low water activity and large exposed surface (small particle size). The use of low temperatures combined with modified atmospheres or vacuum might provide a solution to minimize this deterioration and prolong PNEC shelf life, since a reduction in available $\mathrm{O}_{2}$ has been useful to inhibit microorganism growth (fungi, yeast, and bacteria), to maintain lipid stability, and to reduce nuts' respiration.

PNEC is not used as a food ingredient so its introduction into the food production chain could be important to reduce the economic and ecologic costs of pecan oil production. However, before attempting to use it in the bakery as almond flour is employed, it is important to improve the knowledge on its physicochemical and functional properties and shelf life quality. Thus, the objectives of this work were to characterize the PNEC and to define storage conditions that would assure its microbial and physicochemical quality within a year, making it useful to employ as a food ingredient.

\section{MATERIALS AND METHODS}

\subsection{Materials}

Recently produced PNEC ( $5 \mathrm{~kg}$ ), obtained byfirst cold mechanical pressing of organic certified (OIA, Organización Internacional Agropecuaria) shelled pecan nuts (Nucana, Entre Ríos, Argentina) was processed to obtain a homogeneous sample using a commercial food processor (Universo, Rowenta, Germany, $14 \mathrm{~cm}$ blade) and sieved through a $350 \mu \mathrm{m}$ mesh.

\subsection{Experimental procedure}

Two different permeability films and two temperatures were studied to store samples of $20-40 \mathrm{~g} /$ bag, $1.5 \mathrm{~kg}$ per condition) in dark rooms during a one-year period. The packages used were a low permeability $\left(\mathrm{pO}_{2}=35 \mathrm{~cm}^{3} / \mathrm{m}^{2}\right.$ d at $23{ }^{\circ} \mathrm{C}$ and $\mathrm{pH}_{2} \mathrm{O}=$ $0.2-0.5 \mathrm{~g} / \mathrm{m}^{2} \mathrm{~d}$ ) vacuum package BB4L (Cryovac, Buenos Aires, Argentina), and a high permeability $\left(\mathrm{pO}_{2}=6000-8000 \mathrm{~cm}^{3} / \mathrm{m}^{2} \mathrm{~d}\right.$ at $23{ }^{\circ} \mathrm{C}$ and $\mathrm{pH}_{2} \mathrm{O}=$ 14-17 g/m² d) package PD-960 (Cryovac, Buenos Aires, Argentina). Temperatures of $10{ }^{\circ} \mathrm{C}$ and $20^{\circ} \mathrm{C}$ were chosen.

Four treatments were considered, as a combination of package atmosphere and storage temperature. The nomenclature used was L-10 and L-20 for those samples stored under low permeability vacuum package at 10 and $20{ }^{\circ} \mathrm{C}$, respectively; in the same way, $\mathrm{H}-10$ and $\mathrm{H}-20$ correspond to those stored into the high permeable package at the same temperatures. At different times of storage, samples were taken to analyze possible changes in quality to assure it could be employed in baking or as a food ingredient.

\subsection{Physicochemical and functional properties}

Proximate analysis. The moisture, ash, and protein contents of PNEC were determined in triplicate following standard methods of Analysis of the Association of Official Analytical Chemists (AOAC, 1984). Percent nitrogen was multiplied by 6.25 to obtain percent protein.

Fat content was determined in triplicate by the Soxhlet method, using petroleum ether $\left(\mathrm{Bp}: 35-60^{\circ} \mathrm{C}\right)$ as extraction solvent (Marchetti et al., 2013). Total carbohydrates were determined employing the Anthrone method using glucose as standard (Emelike et al., 2015). Total fiber was determined in duplicate using enzymatic hydrolisis Megazyme kits 991.43 and 958.29 (K-TDRF, Megazyme, Wicklow, Ireland). Water activity was determined in quadruplicate using an Aqualab 4TEV (Decagon Devices INC. MA, USA).

Water and oil absorption. Water and oil absorption capacity (WAC and OAC, respectively) are two 
important functional properties if the pecan expeller would be used as a component in baking products, thus they were characterized as follows.

Water and oil absorptions were determined (Chakraborty, 1986). Briefly, $1 \mathrm{~g}$ of expeller was vortexed with $10 \mathrm{~mL}$ of distilled water or oil using a vortex at the highest speed for 2 min. The mixture was allowed to stand at room temperature for $30 \mathrm{~min}$, and then centrifuged at $3000 \mathrm{~g}$ for $20 \mathrm{~min}$. The supernatant was decanted and the centrifuge tube containing the sediment was weighed.

The results were expressed as $\mathrm{WAC}=\mathrm{mL} / \mathrm{g}$ PNEC and $\mathrm{OAC}=\mathrm{mL} / \mathrm{g}$ PNEC, respectively. Four samples of different packages were analyzed each time.

\subsection{Quality changes during storage}

Microbial quality. Changes in mold and yeast counts in the products were evaluated monthly using the pour plate method. Initial dilution was made by aseptically blending (West Sussex, UK) $20 \mathrm{~g}$ of sample with $180 \mathrm{~mL}$ of $1 \mathrm{~g} / \mathrm{L}$ of peptone solution in a Stomacher blender for $1 \mathrm{~min}$. Appropriate serial dilutions were plated with Yeast Extract Glucose Chloramphenicol Agar (YGC agar, Merck KGaA) incubated for $5 \mathrm{~d}$ at $30^{\circ} \mathrm{C}$.

At the end of storage, appropriate serial dilutions were plated with Plate Count Agar (PCA, Oxoid, Hampshire, UK) for total mesophilic aerobic count (incubated at $30^{\circ} \mathrm{C}$ for $2 \mathrm{~d}$ ) and total psychrotrophic aerobic count (incubated at $4{ }^{\circ} \mathrm{C}$ for $7 \mathrm{~d}$ ), with Violet Red Bile Glucose Agar (Merck KGaA, Darmstadt, Germany) for Enterobacteriaceae (incubated at $37^{\circ} \mathrm{C}$ for $24 \mathrm{~h}$ ), and with de Man, Rogosa, Sharpe agar (MRS agar, Oxoid) for lactic acid bacteria (incubated at $30{ }^{\circ} \mathrm{C}$ for $2 \mathrm{~d}$ ). Data were expressed as $\log$ colony-forming units per gram of sample $(\log \mathrm{CFU} / \mathrm{g})$. Also, total coliform counts using the most probable number method were made (MPN, 46016) (AOAC 1984).

TBARs assay. Thiobarbituric acid reactive substances (TBARS) were determined in quadruplicate according to Pennisi Forell et al. (2010) to evaluate the lipid oxidation in the PNEC stored under different conditions. Results for malondialdehyde (MDA) were expressed as $\mathrm{mg}$ / $\mathrm{kg}$ product.

Fatty acids profile determination. Fatty acids of PNECwere analyzed by GC-MS as fatty acid methyl esters (FAME) at initial time and after 6 and 12 months of storage.

Total lipids of PNEC were extracted using a chloroform-methanol mix (2:1, v/v) according to the Folch et al. (1957) procedure. For the derivatization process, $60 \mathrm{mg}$ of the obtained oil were added to a $10 \mathrm{~mL}$ Falcon conical tube, followed by the addition of $4 \mathrm{~mL}$-hexane and 300 $\mu \mathrm{L} 2 \mathrm{~N}$ methanolic $\mathrm{KOH}$. The solution was mixed vigorously and shaken in a Vortex for $20 \mathrm{~min}$. After that, $0.5 \mathrm{~g}$ of sodium sulphate were added and finally, $1 \mathrm{~mL}$ of the upper phase was separated to be injected.

Fatty acid methyl ester (FAME) content was assayed by Shimadzu GC-MS model QH-2010 Ultra and Hewlett Packard's (HP) model HP-6890. An AT-WAX (Alltech Associates, Inc.) capillary column of length $30 \mathrm{~m}$ and internal diameter of $0.25 \mathrm{x}$ $10^{-3} \mathrm{~m}$ packed with polyethylene glycol $(0.25 \mathrm{~mm}$ film thickness) was used. In QH-2010 Ultra, hydrogen (>99.999\%) was used as a carrier gas at a constant flow rate of $1.4 \mathrm{~mL} / \mathrm{min}$. MS interphase and ion source temperatures were $270^{\circ} \mathrm{C}$ and $220^{\circ} \mathrm{C}$, respectively. The temperatures of the injector and the detector were set at $250{ }^{\circ} \mathrm{C}$ and $270{ }^{\circ} \mathrm{C}$, respectively. The analysis was performed using full MS scan from $\mathrm{m} / \mathrm{z} 50$ to 400 . A solvent delay of $3 \mathrm{~min}$ was used. Injection volume of $1 \mu \mathrm{L}$ and a split ratio of 50:1 were used as part of the GC-MS analysis method. FAME profiles were obtained by comparison of retention times with standard FAME (Supelco 37 Component FAME Mix, Cat. No.18919-1 AMP, Sigma Aldrich) previously analyzed in the same conditions.

Methanol (> 99.5\% purity), n-hexane and sodium sulphate were purchased from J.T. Baker (Mexico); and potassium hydroxide from Analar (UK).

From obtained FAME profiles iodine values (IV) were calculated using the following equation: $\mathrm{IV}=(\%$ oleic acid $\mathrm{x} 0.988)+(\%$ linoleic acid $\mathrm{x}$ $1.814)+(\%$ linolenic acid x 2.737) (Martínez and Maestri, 2008).

\section{Antioxidant activity:}

Extract preparation. For extract preparation $1 \mathrm{~g}$ of PNECwas extracted for $60 \mathrm{~min}$ in $15 \mathrm{~mL}$ of ethanol. Mixtures were centrifuged at $3000 \mathrm{~g}$ for 15 min at $4{ }^{\circ} \mathrm{C}$ and supernatants were properly diluted according to the assay.

DPPH ${ }^{\circ}$ scavenging capacity of pecan expeller cake extracts. The capacity to scavenge the DPPH (2,2-diphenyl-1-picrylhydrazyl) free radical of PNECextracts was monitored (Barman et al., 2013). Various concentrations of extracts $(0.5 \mathrm{~mL})$ were mixed with $2.7 \mathrm{~mL}$ of ethanolic solution containing $\mathrm{DPPH}^{\bullet}$ radicals $(0.2 \mathrm{mmol} / \mathrm{l})$. The mixture was shaken vigorously and left to stand for $90 \mathrm{~min}$ in the dark. The reduction in $\mathrm{DPPH}^{\bullet}$ radical was measured by monitoring absorbance at $517 \mathrm{~nm}$. Radical-scavenging activity was calculated as:

$\%$ DPPH Radical Scavenging Activity $=\frac{A_{\text {Control }}-A_{\text {Extract }}}{A_{\text {Control }}} \times 100$

Eq.1 
Afterwards, \% DPPH radical scavenging activity vs. extract concentration plots were employed to calculate the extract concentration required to scavenge $50 \%$ of DPPH in the assay medium, referred to as $\mathrm{IC}_{50}$. Two extracts were prepared for each treatment and storage time and measurements were done in quadruplicate.

ABTS $^{\circ+}$ radical-scavenging activity. The radicalscavenging activity of the extracts was determined also by the $\mathrm{ABTS}^{\circ+}$ (2,20-azinobis-(3-ethylbenzothiazoline-6-sulphonic acid)) radical cation discoloration assay (Barman et al., 2013). An $\mathrm{ABTS}^{\bullet+}$ radical was generated from the reaction of $5 \mathrm{~mL}$ of 2,20-azinobis-(3-ethylbenzothiazoline-6-sulphonic acid) diammonium salt (ABTS, $7 \mathrm{mM}$ ) in water, with $88 \mathrm{~mL}$ of potassium persulphate $(2.45 \mathrm{mM})$. The mixture was left to stand for $12-16 \mathrm{~h}$ in the dark at room temperature. The absorbance of the reactant was later adjusted to $0.70 \pm 0.02$, at room temperature, at $734 \mathrm{~nm}$.

Different concentrations of PNEC extracts $(0.5 \mathrm{~mL})$ were mixed with $2 \mathrm{~mL}$ of the $\mathrm{ABTS}^{\bullet+}$ solution and the mixtures were shaken during $7 \mathrm{~min}$. The reduction in $\mathrm{ABTS}^{\bullet+}$ radical was determined by reading absorbance at $734 \mathrm{~nm}$. The relationship between $\% \mathrm{ABTS}^{\bullet+}$ scavenged as a function of extract concentration was measured and PNEC extracts were assayed within an appropriate range of dilutions.

$$
\% \text { ABTS Radical Scavenging Activity }=\frac{A_{\text {Control }}-A_{\text {Extract }}}{A_{\text {Control }}} \times 100
$$

Finally, the extract concentration required to scavenge $50 \%$ of ABTS in the assay medium referred to as $\mathrm{IC}_{50}$ (half-maximal inhibitory concentration) was predicted. Two extracts were prepared for each treatment and storage time; measurements were done in quadruplicate.

\subsection{Statistical analysis}

Analysis of variance (ANOVA, SYSTAT, Inc., Evanston, IL, USA) was carried out to test the significance of independent variables. Experimental data were reported as mean values \pm the corresponding standard error of the mean (SEM) when appropriate. For simultaneous pairwise comparisons, the least significance differences (LSD) test was chosen. Differences in means and F-tests were considered significant when $\mathrm{P}<0.05$.

\section{RESULTS AND DISCUSSION}

\subsection{Composition and functional properties}

Table 1 shows the chemical composition of PNEC. Lipid content resulted remarkably high $(51 \mathrm{~g} / 100 \mathrm{~g})$, indicating the possibility to enhance the oil extraction process or enrich the FA profile of other foods by PNEC incorporation. In addition, an important amount of dietary fiber was found, making the expeller cake also a useful component to enhance the nutritional quality of food formulations. PNEC exhibited a similar composition to almond flour (De Pilli et al., 2008), which has important ash $(4.67 \mathrm{~g} / 100 \mathrm{~g})$ and protein contents $(22.24 \mathrm{~g} / 100 \mathrm{~g})$. This indicates that PNEC could be a good substitute for this most commonly used nut-flour. It is interesting to note that in the case of almond flour production, one nut results in one product, but in the case of the pecan nut, one nut results in two products, oil, and cake that is very similar to almond flour (regarding proximate analysis) and could replace it.

Fiber, proteins and carbohydrates are main components of PNEC with the possibility of establishing hydrophilic interactions since these constituents contain hydrophilic parts, such as polar or charged side chains (Jitngarmkusol et al., 2008). In the present work WAC was $1.83 \pm 0.06 \mathrm{~g} \mathrm{H}_{2} \mathrm{O} / \mathrm{g}$ and $\mathrm{OAC}=$ $2.61 \pm 0.09 \mathrm{~g} / \mathrm{g}$. Both parameter values obtained for PNEC were within the range for defatted and full fat pecan flours reported by Joshi et al. (2015). As the results show, PENC-lipid interactions were stronger than interactions with water $(\mathrm{OAC}>\mathrm{WAC})$. Pecan nut proteins may play a key role in this effect since a very low pecan protein solubility compared to several other nuts has been reported (Sathe et al., 2009), indicating weak protein-water interaction. Thus, PNEC exhibited a high oil retention leading to a great number of hydrophobic interactions between the protein and lipid phase. The high water and oil absorption capacity of expeller cake makes it a potential ingredient for the baking industry, were protein and fiber can bridge fat and water in bakery products.

\subsection{Quality characteristics during storage}

Microbial quality. Microbial counts are very important to assure a proper shelf life. high levels of $\mathrm{B}_{1}$ aflatoxins have been reported in Brazil nuts, which exceed the maximum residue limit (De Mello and Scussel, 2007). Therefore, it is important to establish storage conditions with low microbial levels. Changes in mold and yeast counts in products

TABle 1. Proximal composition of pecan nut expeller cake

\begin{tabular}{lc}
\hline Component & $\mathbf{g} / \mathbf{1 0 0} \mathbf{g}$ \\
\hline Lipids & $51.4 \pm 0.1$ \\
Dietary Fiber & $13.6 \pm 0.1$ \\
Proteins & $13.2 \pm 0.01$ \\
Carbohydrates & $11.96 \pm 0.07$ \\
Water & $5.66 \pm 0.03$ \\
Ashes & $3.67 \pm 0.05$ \\
\hline
\end{tabular}

${ }^{\mathrm{a}}$ mean value $\pm \mathrm{SEM}$ 
packaged and stored for one year under different conditions are presented in Figure 1.

PNEC stored in diverse conditions showed no significant differences until day 120. Beyond this time, mold and yeast counts quickly rose for PNEC in high permeability film and $20^{\circ} \mathrm{C}$ and after 220 days samples had to be discarded because of high development.

In addition, extremely low mold and yeast levels were found in PNEC in low permeability vacuum package, regardless of storage temperature $\left(10^{\circ} \mathrm{C}\right.$ or $20^{\circ} \mathrm{C}$ ). Thus, this seems to be the main control parameter for microbial spoilage. When a high permeable film was employed microbial levels exhibited significant differences between temperatures.

PNEC stored in high permeability film (H-10) and $10{ }^{\circ} \mathrm{C}$ showed similar microbial quality to low permeability vacuum package at both temperatures during the first 9 months, being significantly different from day 300 on. However, three treatments showed very low $\log \mathrm{CFU} / \mathrm{g}$ values at the end of experiment.

At the end of storage, treatments with low mold and yeast counts (L-10, L-20, and H-10) were tested for other microorganisms. Nevertheless, total aerobic mesophilic and psychrotrophic, Enterobacteriaceae, lactic acid bacteria, and total coliforms were below detection limits, probably due to the low water $\operatorname{activity}\left(\mathrm{a}_{\mathrm{w}}\right)$ of PNEC $(0.59 \pm 0.05)$.
TBARs and fatty acid profile. The FA profile obtained for PNEC at $\mathrm{t}=0$ days (Table 2 ) was found to be similar to those reported by Fernandes et al. (2017) for pecan oil. The amounts of monounsaturated FA (MUFA) and polyunsaturated FA (PUFA) were 63.27 and $29.93 \mathrm{~g} / 100 \mathrm{~g}$, respectively, with lower saturated FA(SFA) levels $(6.09 \mathrm{~g} / 100 \mathrm{~g})$. The main PNEC unsaturated FA were oleic and linoleic acids, with 65.1 and $28.6 \mathrm{~g} / 100 \mathrm{~g}$, respectively, followed by linolenic acid.

In recent years a variety of studies have demonstrated that dietary polyunsaturated fatty acids have protective effects on metabolic syndrome diseases such as type 2 diabetes, hyperlipidemia, or cardiovascular disease (Koba and Yanagita, 2014). Equally, promising results are now available regarding their positive effects on inflammatory diseases, cancer, and osteoporosis (Moon et al., 2012). The use of PNEC in cereal mixes, cereal bars, or bakery products would be a good alternative to provide high contents of oleic and linoleic acids, and also linolenic acid, and thus enhance the nutritional quality of foods.

As the TBARs methodology is commonly employed for monitoring secondary oxidation products, i.e., aldehydes or carbonyls, which may contribute to the off-flavor of oxidized oils (Haq et al., 2013), TBARS evolution was employed to follow PNEC lipid oxidation in this work. As can be

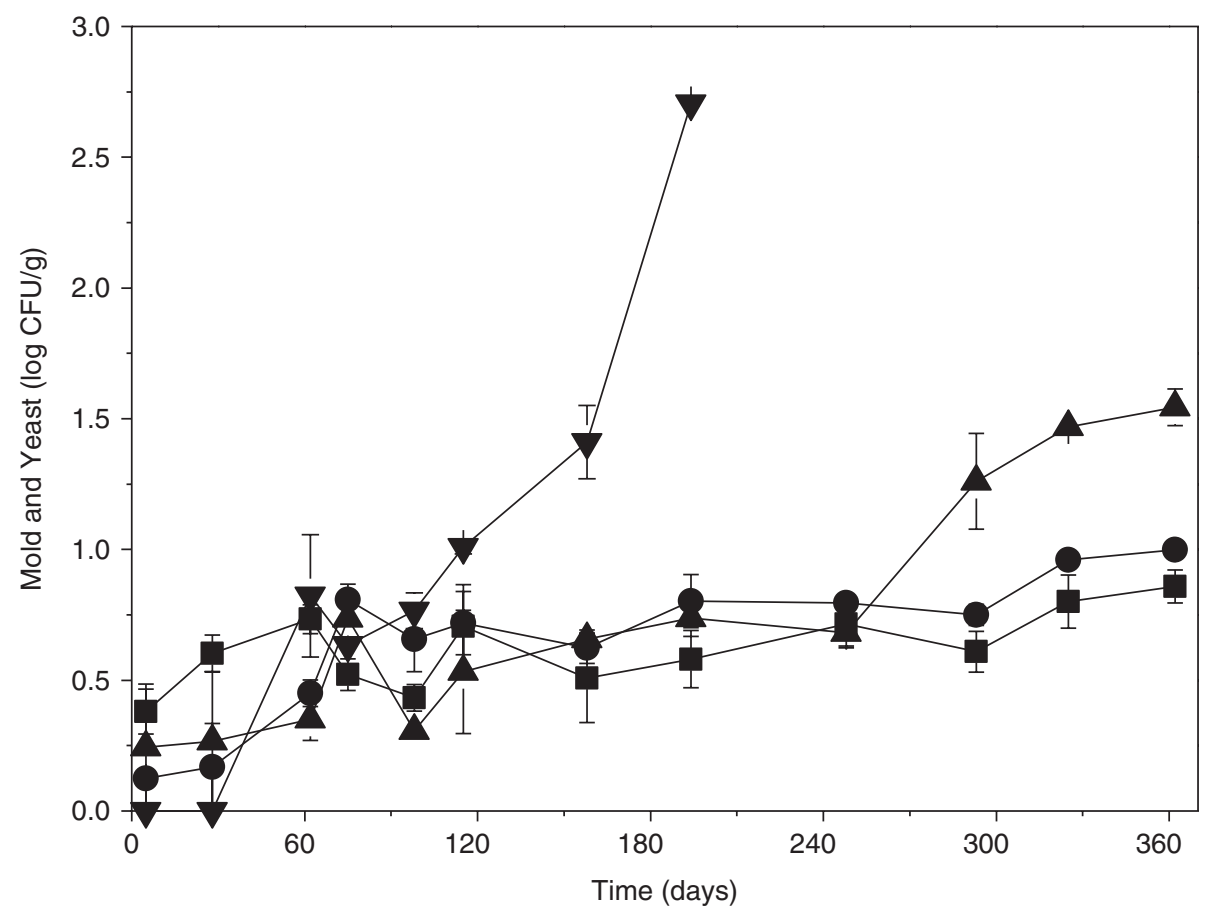

FIGURE 1. Effect of storage conditions on mold and yeast growth in pecan nut expeller cake stored: under vacuum at $10{ }^{\circ} \mathrm{C}(\mathrm{L}-10$, and $20^{\circ} \mathrm{C}(\mathrm{L}-20, \bullet)$, in normal atmosphere at $10^{\circ} \mathrm{C}(\mathrm{H}-10, \boldsymbol{\Delta})$ and $20^{\circ} \mathrm{C}(\mathrm{H}-20, \boldsymbol{\nabla})$. Error bars indicate SEM. 


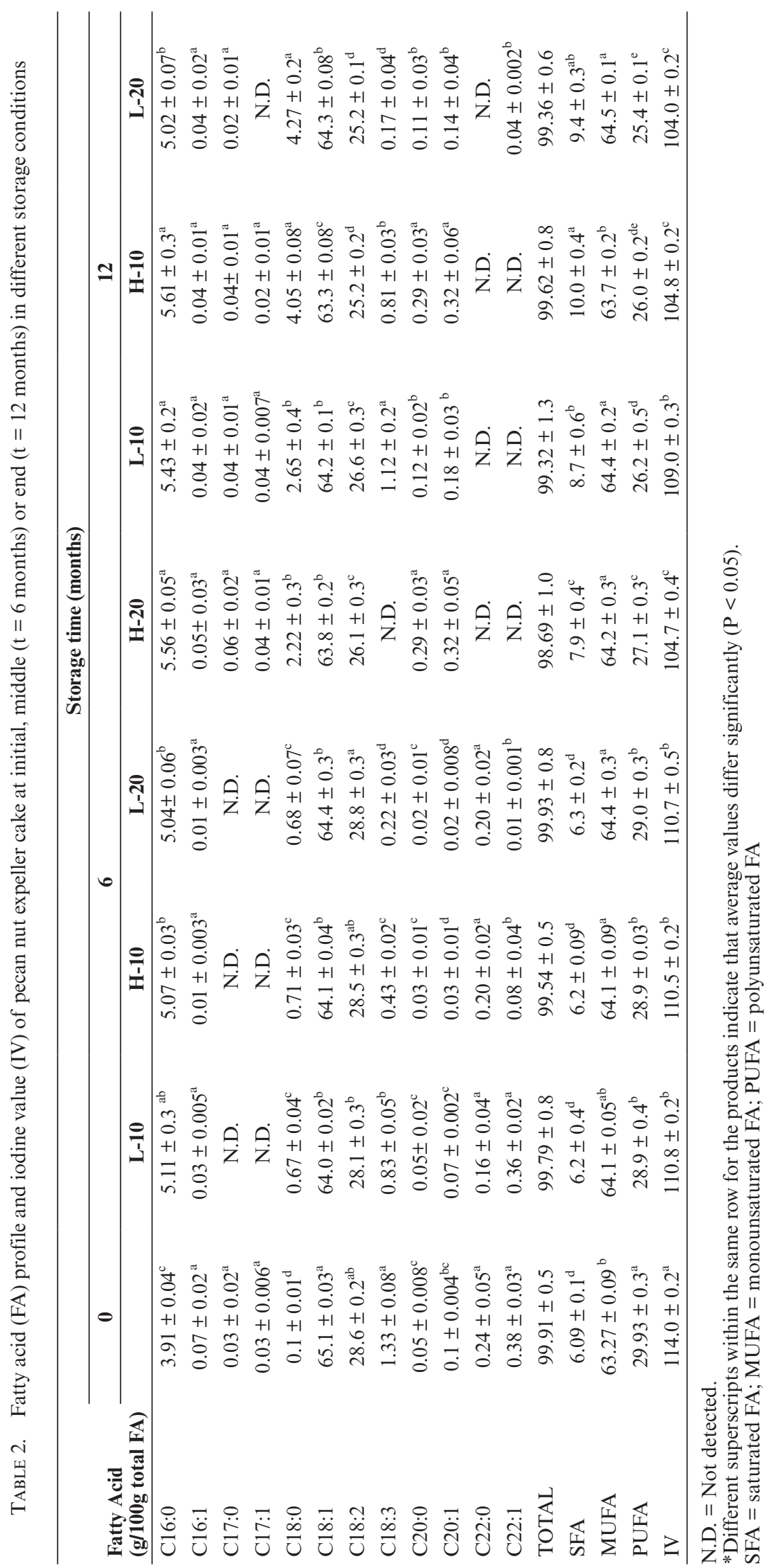


seen in Figure 2, oxygen restriction had a significant effect on lipid stability. PNEC in a low permeability vacuum package was stable, regardless of the temperature, showing a slight TBARs number increase in MDA from 0.05 to $0.2 \mathrm{mg} / \mathrm{kg}$ PNEC at the end of storage, which demonstrates an excellent oxidative stability.

On the other hand, the use of a high permeability film facilitated lipid oxidation. In PNEC stored without $\mathrm{O}_{2}$ restriction and maintained at $10{ }^{\circ} \mathrm{C}(\mathrm{H}-10)$ TBARs remained constant up to day 225 , when a sharp increase (>1 mg/kg PNEC) was observed, indicating an oxidative spoilage which could be potentially harmful (Kofakowska, 2010). As expected, PNEC kept at $20^{\circ} \mathrm{C}$ in high permeability film $(\mathrm{H}-20)$ exhibited a significant TBARs increase sooner (day 180), resulting in mold and yeast growth and determining the end of the shelf life.

These results showed that both temperatures (10 and $20^{\circ} \mathrm{C}$ ) combined with vacuum package in a low permeability film could preserve PNEC during one year. Other authors had suggested a temperature of $10{ }^{\circ} \mathrm{C}$ and oxygen restriction as optimal conditions for a 12 month-shelf life for shelled walnuts, similar to our results for PNEC, as secondary oxidation and rancidity flavor development were critical parameters to control (Jensen et al., 2003).

From the FA profile analyses (Table 2), it can be seen that L-10, H-10 and L-20 treatments could protect unsaturated fatty acids for up to 6 months, since only minor changes were observed. $\mathrm{H}-20$ profiles exhibited a significant decrease in C18:3, indicating an oxidation of this FA. After 12 months of storage, L-10 showed a better performance than the other two treatments (H-10 and L-20). The level of C18:3 remained unchanged and C18:2 showed a slight decrease.

SFA are the most stable fatty acids and it is not expected to detect a change in their total content. Nevertheless, the observed C16:0 proportional increment is a consequence of MUFA and PUFA percentage reduction through peroxidation.

The FA profiles and observed changes at the end of vacuum-packaged refrigerated storage are in agreement with results obtained in TBARs assay, where an $\mathrm{O}_{2}$ restrictive barrier resulted in an effective method to preserve PNEC unsaturated FA. In addition, lowering storage temperature delayed lipid oxidation. Estimated iodine values (Table 2) are in agreement with the above mentioned results. A significant decrease in IV was observed at 6 months of storage for all the different conditions, indicating an oxidation process that progressed in L-20 and $\mathrm{H}-10$ lowering IV until the end of storage, but was inhibited in L-10 as no further changes were observed.

Antioxidant capacity. Figure 3 and Figure 4 show the results of antioxidant capacity in terms of $\mathrm{DPPH}^{\bullet}$ scavenging activity and $\mathrm{ABTS}^{\bullet+}$ radical,

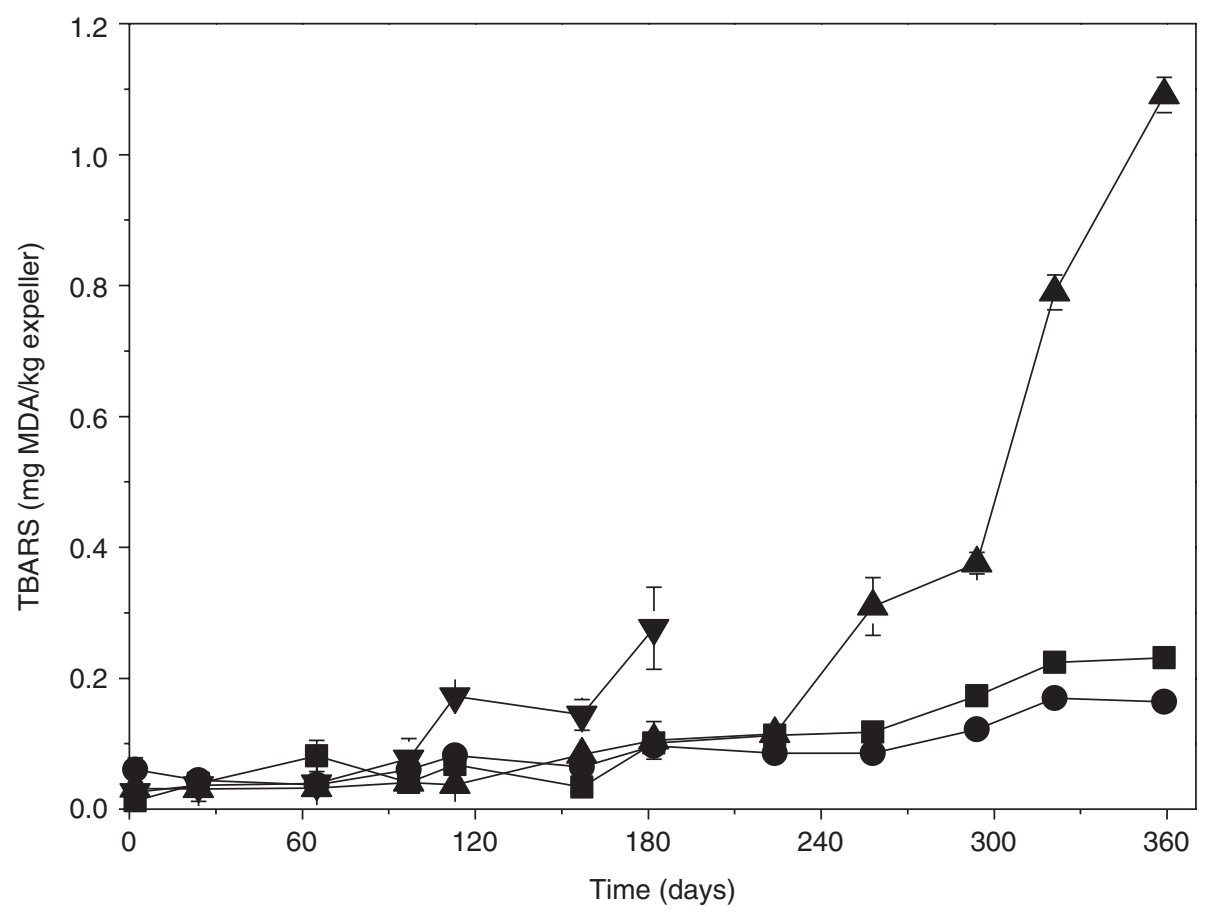

FIGURE 2. Effect of storage conditions on TBARs evolution (expressed as milligrams of malonaldehyde, MDA/ kg product) of pecan nut expeller cakestored: under vacuum at $10^{\circ} \mathrm{C}(\mathrm{L}-10, \boldsymbol{\nabla})$ and $20^{\circ} \mathrm{C}(\mathrm{L}-20, \bullet)$, in normal atmosphere at $10^{\circ} \mathrm{C}(\mathrm{H}-10, \boldsymbol{\Delta})$ and 20 ${ }^{\circ} \mathrm{C}(\mathrm{H}-20, \boldsymbol{\nabla})$. Error bars indicate SEM. 


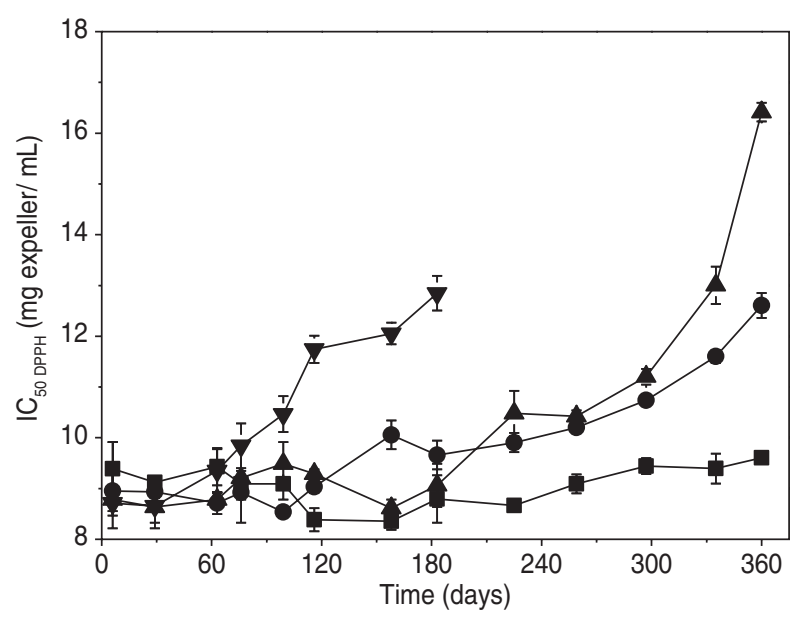

FIGURE 3. Effect of storage conditions on antioxidant activity of pecan nut expellercake against $\mathrm{DPPH}^{\bullet}$, expressed as $\mathrm{IC}_{50}$ (extract concentration required to scavenge $50 \%$ of the $\mathrm{DPPH}^{\bullet}$ in the assay medium): stored under vacuum at $10^{\circ} \mathrm{C}(\mathrm{L}-10, \mathbf{\square})$ and $20^{\circ} \mathrm{C}\left(\mathrm{L}-20,{ }^{\circ}\right)$, stored in more permeable film at $10^{\circ} \mathrm{C}$

$(\mathrm{H}-10, \boldsymbol{\Delta})$ and $20{ }^{\circ} \mathrm{C}(\mathrm{H}-20, \boldsymbol{\nabla})$. Error bars indicate SEM.

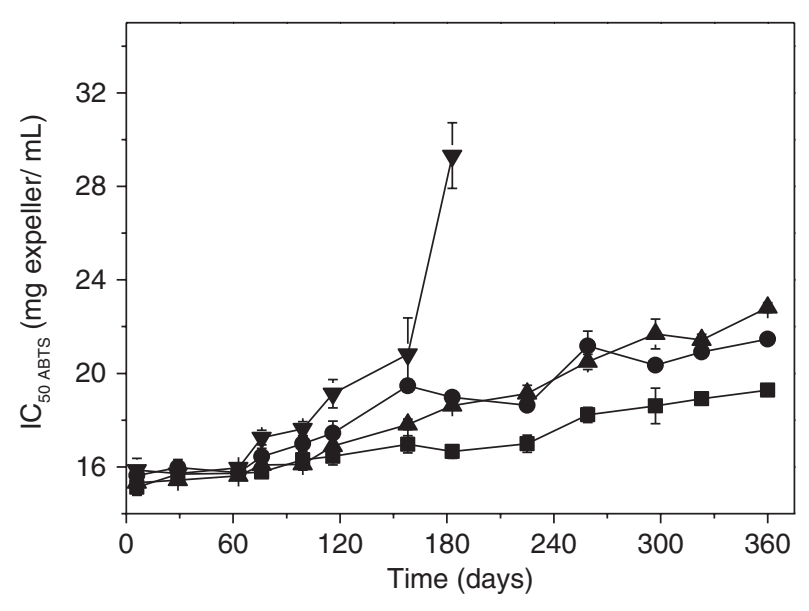

FIGURE 4. Effect of storage conditions on antioxidant activity of pecan nut expellercakeagainst $\mathrm{ABTS}^{\bullet+}$, expressed as $\mathrm{IC}_{50}$ (extract concentration required to scavenge $50 \%$ of the ABTS in the assay medium): stored under vacuum at $10{ }^{\circ} \mathrm{C}(\mathrm{L}-10, \mathbf{0})$ and $20^{\circ} \mathrm{C}\left(\mathrm{L}-20,{ }^{\circ}\right)$, stored in more permeable film at $10^{\circ} \mathrm{C}$

$(\mathrm{H}-10, \boldsymbol{\Delta})$ and $20{ }^{\circ} \mathrm{C}(\mathrm{H}-20, \boldsymbol{\nabla})$. Error bars indicate SEM.

respectively. As can be seen in Figure 3 the antioxidant capacities of ethanolic extracts $(t=0 d)$ of PNEC were high and presented similar or higher values than those reported for hazelnuts and pecan nut kernels $\mathrm{IC}_{50}$ (Salvador et al., 2016). This suggests that cold pressed extraction did not negatively affect antioxidant capacity, and that the pecan nut's main antioxidants were not extracted in the oil showing a predominantly hydrophilic nature of the compounds. There are precedents that support this conclusion. Gentile et al. (2007) reported that the antioxidant activity of a lipophilic extract was much lower than that of the hydrophilic one in pistachio kernels. Also Wu et al. (2004) informed that watersoluble components contribute $>90 \%$ to the total antioxidant potential of most foods.

Both antioxidant mechanisms studied (DDPH ${ }^{\bullet}$ and $\mathrm{ABTS}^{\bullet+}$ ) reflected similar tendencies during storage. It is noteworthy that only samples maintained at $10{ }^{\circ} \mathrm{C}$ with $\mathrm{O}_{2}$ restriction presented similar $\mathrm{DPPH}^{\bullet}$ values within 365 days of storage and a slightly increase in $\mathrm{ABTS}^{\bullet+} \mathrm{IC}_{50}$. This suggests that under these conditions the lipid oxidation process is clearly inhibited because the antioxidant potential of the sample remained almost unchanged.

On the other hand, $10{ }^{\circ} \mathrm{C}$ with normal atmosphere (H-10), and $20{ }^{\circ} \mathrm{C}$ with $\mathrm{O}_{2}$ restriction (L-20) are conditions that can prevent or delay lipid oxidation, as seen previously in Figure 2, but antioxidant potential is reduced by $50 \%$. This indicates that antioxidants in the sample are reduced through an incipient oxidation or other process.

It has been reported that pecan nuts have high levels of tocopherols ( $>200 \mathrm{mg} / \mathrm{kg}$, Fernandes et al., 2017), with a high proportion of $\gamma$-tocopherol as the isomer with the highest in-vitro antioxidant capacity. This may lead to an important antioxidant capacity of PNEC (Miraliakbari and Shahidi, 2008).

Although both methods measure antioxidant capacity, their mechanisms are different. The ABTS $^{\circ+}$ assay measures antioxidant capacity based on the ability of the antioxidant to scavenge the blue-green colored ABTS radical cation by electron donation, while the DPPH${ }^{\bullet}$ method determines the hydrogen donating capacity of a molecule and does not produce oxidative chain reactions or react with free radical intermediates. In spite of these differences there was a significant correlation $(\mathrm{P}<0.05)$ between both $\mathrm{IC}_{50}$ values.

Miraliakbari and Shahidi (2008) affirmed that besides tocopherols, other antioxidative minor components of tree nut oils include phospholipids, phytosterols, and phytosterol conjugates, and possibly non-tocopherol phenolics, among others. Synergistic antioxidant activities have been reported between tocopherols and nitrogen-containing phospholipids such as phosphatidylcholine, phosphatidylethanolamine and phosphatidylserine, all of which are present in tree nut oils and their minor component extracts and may help explain the high antioxidant activities observed for these products. Antioxidant capacity has been previously used as an indicator of the overall quality and oxidative stability of oils with good accuracy (Castelo-Branco et al., 2016). In the present paper we found similar trends in TBARS and antioxidants assays.

Considering the four treatments employed and the different shelf life aspects studied, we can conclude that H-20 treatment was a proper storage condition only for short periods of time (4-5 months) because of microbial growth and the consequent risk 
of aflatoxin development. Lowering the temperature (H-10) would control the microbial growth but at eighth months lipid peroxidation became a problem and product quality could not be assured. Finally, employing a more effective barrier (L-20 and L-10) would solve these issues, nevertheless L-20 seemed to have suffered some antioxidant loss, and had a less protective effect over FA than L-10, which resulted in the best treatment for assuring long shelf life.

\section{CONCLUSIONS}

PNEC was rich in unsaturated lipids, fiber, and ashes (minerals). Its high water and oil absorption capacities indicated that it could be used as a component in bakery products. Properly storage conditions were established to guarantee the optimum quality of PNEC for a year. Oxygen restriction inhibited mold and yeast development and lipid oxidation with consequent protection of fatty acids and antioxidants present in this product. At the end of the study (12 months), the combination of $20{ }^{\circ} \mathrm{C}$ and $\mathrm{O}_{2}$ restriction resulted in a good storage condition, with slight levels of oxidation and loss in antioxidant capacity. In addition, the use of low temperatures $\left(10^{\circ} \mathrm{C}\right)$ and vacuum packaging allowed for maintaining PNEC quality: good water and oil absorption capacities, high content of unsaturated fatty acids, controlled lipid oxidation, and preserved antioxidant capacity. Establishing the proper conditions to assure PNEC quality would contribute to its inclusion in different foods since has an important dietary fiber content and high quantity of unsaturated fatty acids, making it a good choice to enhance these components in foods such as bakery products or cereal bars.

\section{ACKNOWLEDGMENTS}

This research was supported by Consejo Nacional de Investigaciones Científicas y Técnicas (CONICET, Argentina) and Universidad Nacional de La Plata. In addition, the authors thank NUCANA S.A. (Entre Ríos, Argentina) for providing the PNEC used.

\section{REFERENCES}

AOAC Methods 24.003, 24.009, and 24.027. 1984. Official methods of analysis of Association of Official Analytical Chemists AOAC International, Rockville, MD, USA.

Barman N, Sharma A, Kumar A. 2013. Radical scavenging and antioxidant potential of nuts and leaves extracts of Semecarpus anacardium L. Am. J. Plant Sci. 4, 1679-1683. http://dx.doi.org/10.4236/ajps.2013.48204

Bartosz G, Kofakowska A. 2010. Lipid oxidation in food systems. In Sikorski ZZE and Kolakowska A (Eds.) Chemical and functional properties of food lipids. CRC Press, London, 133-166.

Castelo-Branco VN, Santana I, Di-Sarli VO, Freitas SP, Torres AG. 2016. Antioxidant capacity is a surrogate measure of the quality and stability of vegetable oils. Eur. $J$. Lipid. Sci. Tech. 118, 224-235. http://dx.doi.org/10.1002/ ejlt.201400299
Cockerham S, Gorman W, Maness N, Lillywhite J. 2012. Feasibility assessment of investing in a pecan oil and flour processing facility using new extraction technology. Available at: http://aces.nmsu.edu/pubs/research/economics/RR778.pdf (Accesed 19-06-2017).

Chakraborty P. 1986. Coconut protein isolate by ultrafiltration. In LeMeguer M, Jelen P (Eds.) Food engineering and process applications (Vol. 2, pp. 308-315). New York: Elsevier Applied Science Publishers.

De Mello FR, Scussel VM. 2007. Characteristics of in-shell Brazil nuts and their relationship to aflatoxin contamination: criteria for sorting. J. Agric. Food Chem. 55, 93059310. http://dx.doi.org/10.1021/jf071392x

De Pilli T, Jouppila K, Ikonen J, Kansikas J, Derossi A, Severini C. 2008. Study on formation of starch-lipid complexes during extrusion-cooking of almond flour. J. Food Eng. 87, 495-504. https://doi.org/10.1016/j.jfoodeng.2007.12.028

Emelike N, Barber L, Ebere C. 2015. Proximate, mineral and functional properties of defatted and undefatted cashew (Anacardium occidentale linn.) kernel flour. Eur. J. Food Sci. Tech. 3, 11-19.

Fernandes GD, Gómez-Coca RB, Pérez-Camino MC, Moreda W, Barrera-Arellano, D. 2017. Chemical characterization of major and minor compounds of nut oils: almond, hazelnut, and pecan nut. J. Chem- $N Y$. Article in press. https:// doi.org/10.1155/2017/2609549

Folch J, Lees M, Sloane-Stanley G. 1957. A simple method for the isolation and purification of total lipids from animal tissues. J. Biol. Chem. 226, 497-509.

Gentile C, Tesoriere L, Butera D, Fazzari M, Monastero M, Allegra M, Livrea, M.A. 2007. Antioxidant activity of Sicilian pistachio (Pistacia vera $\mathrm{L}$. var. Bronte) nut extract and its bioactive components. J. Agric. Food Chem. 55, 643-648. https://doi.org/10.1021/jf062533i

Hal, GD. 2000. Pecan food potential in prehistoric North America. Econ. Bot. 54, 103-112. https://doi.org/10.1007/ BF02866604

Haq MA, Alam MJ, Hasnain A. 2013. Gum Cordia: A novel edible coating to increase the shelf life of Chilgoza (Pinus gerardiana). LWT. 50, 306-311. https://doi.org/10.1016/j. lwt.2012.05.008

Haytowitz D, Bhagwat S, Harnly J, Holden J, Gebhardt S. 2006. Sources of flavonoids in the US diet using USDA's updated database on the flavonoid content of selected foods. Available at: https://www.ars.usda.gov/ARSUserFiles/80400525/ Articles/AICR06 flav.pdf (Accesed 19-06-2017).

Jensen PN, Sørensen G, Brockhoff P, Bertelsen G. 2003. Investigation of packaging systems for shelled walnuts based on oxygen absorbers. J. Agric. Food Chem. 51, 49414947. https://doi.org/10.1021/jf021206h

Jitngarmkusol S, Hongsuwankul J, Tananuwong K. 2008. Chemical compositions, functional properties, and microstructure of defatted macadamia flours. Food Chem. 110, 23-30. https://doi.org/10.1016/j.foodchem.2008.01.050

Joshi AU, Liu C, Sathe SK. 2015. Functional properties of select seed flours. $L W T$ 60, 325-331. https://doi.org/10.1016/j. lwt.2014.08.038

Koba K, Yanagita T. 2014. Health benefits of conjugated linoleic acid (CLA). Obes. Res. Clin. Prac. 8, e525-e532. https://doi.org/10.1016/j.orcp.2013.10.001

Marchetti L, Andrés S, Califano A. 2013. Textural and thermal properties of low-lipid meat emulsions formulated with fish oil and different binders. LWT 51, 514-523. https:// doi.org/10.1016/j.lwt.2012.12.006

Martínez ML, Maestri DM. 2008. Oil chemical variation in walnut (Juglans regia L.) genotypes grown in Argentina. Eur. J. Lipid Sci Tech. 110, 1183-1189. https://doi.org/10.1002/ ejlt.200800121

Miraliakbari H, Shahidi F. 2008. Oxidative stability of tree nut oils. J. Agric. Food Chem. 56, 4751-4759. https://doi. org/10.1021/jf8000982

Moon HJ, Kim TH, Byun DW, Park Y. 2012. Positive correlation between erythrocyte levels of $n-3$ polyunsaturated fatty acids and bone mass in postmenopausal Korean women with osteoporosis. Ann. Nutr. Metab. 60, 146-153. https://doi.org/10.1159/000337302 
Pennisi Forell SC, Ranalli N, Zaritzky NE, Andrés SC, Califano AN. 2010. Effect of type of emulsifiers and antioxidants on oxidative stability, colour and fatty acid profile of low-fat beef burgers enriched with unsaturated fatty acids and phytosterols. Meat. Sci. 86, 364-370. https://doi.org/10.1016/j. meatsci.2010.05.015

Pinheiro do Prado AC, Monalise Aragão A, Fett R, Block JM. 2009. Antioxidant properties of pecan nut [Carya illinoinensis (Wangenh.) C. Koch] shell infusion. Grasas Aceites 60, 330-335. http://dx.doi.org/10.3989/gya.107708

Salvador A, Podestá R, Block J, Ferreira S. 2016. Increasing the value of pecan nut [Carya illinoinensis (Wangenh) C. Koch] cake by means of oil extraction and antioxidant activity evaluation. J. Supercrit. Fluids 116, 215-222. https://doi. org/10.1016/j.supflu.2016.05.046
Sathe SK, Venkatachalam M, Sharma GM, Kshirsagar HH, Teuber SS, Roux KH. 2009. Solubilization and electrophoretic characterization of select edible nut seed proteins. $J$ Agr. Food Chem. 57, 7846-7856. https://doi.org/10.1021/jf9016338 USDA. 2016. United States Department of Agriculture. Agricultural Research Service National Nutrient Database for Standard Reference. Available at: http://ndb.nal.usda. gov/ndb/foods (Accessed 02-10-2016).

Walsh R. 2016. Healthy but flavorless pecan oil. Available at: http://www.houstonpress.com/restaurants/healthy-but-flavorless-pecan-oil-6406713 (Accessed 02-10-2016).

Wu X, Beecher GR, Holden JM, Haytowitz DB, Gebhardt SE, Prior RL. 2004. Lipophilic and hydrophilic antioxidant capacities of common foods in the United States. J. Agric. Food Chem. 52, 4026-4037. https://doi.org/10.1021/jf049696w 